\title{
Pengaruh Konsentrasi Ekstrak Daun Hokianti Mikro (Carmona Retusa) Terhadap Dye Sensitized Solar Cell (DSSC)
}

\section{Effect of Hokianti Mikro (Carmona Retusa) Leaves Extract Concentration on Dye Sensitized Solar Cell (DSSC)}

\author{
Kadek Ayu Rahmanuca Sabathiningsih ${ }^{1}$, I Gusti Agung Putra Adnyana ${ }^{1 *}$, Ni Luh Putu \\ Trisnawati $^{1}$ \\ ${ }^{1}$ Jurus an Fisika, Fakultas Matematika dan Ilmu Pengetahuan Alam, Univers itas Udayana, Kampus Bukit \\ Jimbaran, Badung, Bali, Indonesia 80361 \\ Email: ayusabathiningsih@gmail.com; *igaadnyana@unud.ac.id; trisnawati@unud.ac.id
}

\begin{abstract}
Abs trak - Telah dilakukan penelitian tentang fabrikasi DSSC menggunakan daun Hokianti mikro (carmona retusa) sebagai dye alami berbasis antosian. DSSC dibuat dengan menggunakan semikonduktor $\mathrm{TiO}_{2}$ yang dilapiskan pada kaca konduktif Indium Tin Oxide (ITO) dengan variasi konsentrasi dye daun Hokianti mikro sebesar 60, 75 dan $90 \mathrm{mg} / \mathrm{mL}$ dan variasi warna lampu penyinaran pada DSSCyaitumerah, orange, hijau, birudan putih. Padapenelitian ini, hasilkarakterisasi dengan spektofotometer FTIR menunjukkan bahwa sampel mengandung gugus fungsi cincin aromatik yang berperan sebagai antosianin. Analisis dengan SEM memperlihatkan morfologi pe rmukaan sampel terdapat tumpukan butiran-butiran dengan batas-batas yang jelas sehing ga dapat diperoleh ukuran diameter butiran sekitar $(54,13 \pm 0,62) \mu m$. Karakterisasi dye sampel dengan menggunakan spektrofotometer UV-Vis pada tiga konsentrasi 60 , 75 dan $90 \mathrm{mg} / \mathrm{mL}$ menyerap cahaya pada daerah $U V$ yaitu pada rentang panjang gelombang 200-400 $\mathrm{nm}$ dengan nilai absorbansi berturut-turut sebesar 0,4271, 0,4275 dan 0,5449. Nilai absorbansi maksimum terjadi pada konsentrasi $90 \mathrm{mg} / \mathrm{mL}$ yaitu sebesar 0,5449. Hasilkarakterisasi I-V menunjukkan bahwa variasi konsentrasidye sampel sebesar 60, 75 dan $90 \mathrm{mg} / \mathrm{mL}$ berpengaruh terhadap nilai efisiensi DSSC dengan nilai efisiensi tertinggi pada warna lampumerah, orange, hijau, biru dan putih berturut-turut 0,272\%, 1,008\%, 1,536\%, 1,632\% dan 2,080\%. Nilai efisiensi maksimum terjadi pada konsentrasi $90 \mathrm{mg} / \mathrm{mL}$ yang disinari warna lampu putih sebesar $2,080 \%$.
\end{abstract}

Kata kunci: Daun Hokianti Mikro, DSSC, variasi konsentrasi dye, karakterisasi I-V, nilai efisiensi.

\begin{abstract}
Abs tract - The research on DSSCfabrication has been carried out using Hokiantimicro leaf (carmona retusa) as an anthocyanin-based natural dye. DSSC is made using a $\mathrm{TiO}_{2}$ semiconductor coated on indium tin oxide (ITO) conductive glass with variations in the concentration of Hokianti micro leaf dye of 60,75 and $90 \mathrm{mg} / \mathrm{mL}$ and variations in the color of the irradiation lamp on the DSSC, namely red, orange, green, blue and white. In this study, the results of characterization by FTIR spectrophotometer showed that the sample contained an aromatic ring functional group that acted as anthocyanin. Analysis with SEM showed that the surface morphology of the sample contained piles of grains with clear boundaries so that the grain diameter size could be obtained was approximately (54.13 \pm 0.62$) \mu \mathrm{m}$. Characterization of sample dye using UV-Vis spectrophotometer at three concentrations of 60, 75 and $90 \mathrm{mg} / \mathrm{mL}$ absorbs light in the UV region, namely in the wavelength range of 200-400 $\mathrm{nm}$ with absorbance values of 0.4271, 0.4275 and 0.5449. The maximum absorbance value occurs at a concentration of $90 \mathrm{mg} / \mathrm{mL}$, which is 0.5449 . The results of characterization I-V showed that variations in the sample dye concentration of 60,75 and $90 \mathrm{mg} / \mathrm{mL}$ affected the efficiency of DSSC with the highest efficiency values in red, orange, green, blue and white light colors, respectively $0.272 \%, 1.008 \%$, $1.536 \%, 1.632 \%$ and $2.080 \%$. The maximum efficiency value occurs at a concentration of $90 \mathrm{mg} / \mathrm{mL}$ illuminated by white light of $2.080 \%$.
\end{abstract}

Key words: Hokianti micro leaves, DSSC, variation of dye concentration, I-V characterization, efficiency value.

\section{Pendahuluan}

Indonesia memiliki potensi energi terbarukan yang sangat besar, seperti tenaga air, panas bumi, biomassa, angin dan surya yang bersih dan ramah lingkungan, namun pemanfaatannya belum ideal. 
Secara geografis, Indonesia terletak di garis khatulistiwa, sehingga Indonesia memiliki sumber energi matahari yang melimpah, dengan rata-rata intensitas radiasi matahari di seluruh Indonesia sekitar 4,8 $\mathrm{kWh} / \mathrm{m}^{2}$ per hari [1]. Indonesia memiliki energi surya yang melimpah dan berpotensi untuk mengembangkan sel surya sebagai sumber energi alternatif.

Energi surya memungkinkan sebagai pembangkit energi di daerah-daerah terpencil. Hal inilah yang menjadi dasar dilakukannya pengembangan penelitian dalam pembuatan sel surya. Sel surya berbasis silikon merupakan jenis sel surya yang banyak digunakan saat ini. Walaupun sel surya sekarang didominasi oleh bahan silikon, masalah mahalnya biaya produksi dan proses fabrikasinya yang tidak sederhana menjadi suatu kendala [2].

Dengan perkembangan teknologi, dominasi ini secara bertahap digantikan oleh sel surya generasi terbaru, yaitu dye sensitized solar cell (DSSC). Keunggulan DSSC adalah tidak memerlukan bahan dengan kemurnian tinggi, sehingga biaya produksi relatif rendah [3]. Selain itu, tidak seperti sel surya konvensional dimana semua proses melibatkan bahan silikon itu sendiri, pada DSSC penyerapan cahaya dan pemisahan muatan terjadi dalam proses yang berbeda. Penyerapan cahaya dilakukan oleh molekul zat pewarna (dye) dan pemisahan muatan dilakukan oleh semikonduktor anorganik celah pita lebar. Salah satu semikonduktor yang sering digunakan adalah titanium dioksida $\left(\mathrm{TiO}_{2}\right)$. Hal ini karena $\mathrm{TiO}_{2} \mathrm{relatif}$ murah, umum dan tidak beracun [4].

Sensitizer DSSC sering menggunakan antosianin yang berasal dari pigmen alami. Hal ini dikarenakan antosianin memiliki keunggulan yang lebih dibandingkan klorofil [5]. Senyawa antosianin memiliki gugus karbonil dan gugus hidroksil dalam struktur molekulnya, sehingga dapat berikatan secara kimia dengan permukaan $\mathrm{TiO}_{2}$.

Pada penelitian ini menggunakan daun Hokianti mikro atau dalam istilah awam dikenal dengan kesinen sebagai sensitizer DSSC. Kandungan kimia daun Hokianti mikro yaitu asam rosmarinik, flavonoid dan triterpenoid [6]. Flavonoid adalah kelompok pigmen antosianin yang banyak tersebar pada organ tanaman, terutama pada bagian daun tanaman [7], sehingga daun Hokianti mikro mengandung antosianin yang dapat digunakan sebagai $d y e$ pada DSSC. Fabrikasi DSSC pada penelitian ini disusun dari beberapa komponen antara lain, semikonduktor $\mathrm{TiO}_{2}$, lapisan dye dari daun Hokianti mikro, counter elektroda dan elektrolit yang selanjutnya akan diuji dengan berbagai panjang gelombang cahaya untuk mengetahui sensitifitasnya.

\section{Landasan Teori}

\subsection{Dye sensitized solar cell (DSSC)}

DSSC yaitu suatu perangkat sel surya berbasis fotoelektrokimia yang melibatkan transfer muatan dari satu fase ke fase lainnya. Jenis sel surya ini pertama kali ditemukan pada tahun 1991 oleh Michael Gratzel dan Brian O'Regan yang disebut dengan Gratzel Cells. Efisiensi DSSC lebih rendah dari sel surya silikon, mencapai 17-25\% [8]. Sejauh ini efisiensi maksimum pada DSSC yang diperoleh adalah $10 \%$ [4].

DSSC berstruktur sandwich tersusun dari beberapa komponen yaitu elektroda kerja, elektroda pembanding (counter elektroda) dan larutan elektrolit seperti ditunjukkan pada Gambar 1. Elektroda kerja merupakan lapisan tipis yang terdiri dari bahan semikonduktor $\mathrm{TiO}_{2}$ transparan berkonduksi (Indium Tin Oxide, ITO) dan dye alami sebagai sensitizer. Dalam DSSC, dye alami berperan penting dalam menyerap foton dari sinar matahari atau lampu dan mengubahnya menjadi arus listrik [9].

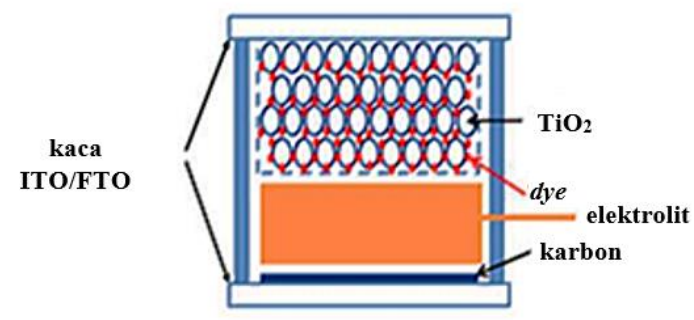

Gambar 1. Susunan satu sel DSSC seperti sandwich [10]. 


\subsection{Dye daun Hokianti mikro (carmona retusa)}

Berbagai jenis buah, bunga atau daun dapat digunakan sebagai sumber fotosensitiser alami yang murah dan ramah lingkungan untuk produksi sel surya berbasis sensitizer dye. Flavonoid seperti antosianin $\left(\mathrm{C}_{15} \mathrm{H}_{12} \mathrm{O}_{6}\right)$ yang terdapat dalam struktur daun, buah dan bunga yang bersifat stabil dan beberapa pigmen antosianin bisa digunakan sebagai sensitizer [10]. Serapan maksimum dari ekstrak antosianin berkisar di daerah antara 510-548 nm. Kinerja ekstrak alami biasanya lebih baik daripada senyawa komersial atau hasil pemurnian yang serupa, hal ini mungkin karena adanya campuran dye pada beberapa ekstrak [10]. Dye yang berbeda menghasilkan serapan cahaya dengan panjang gelombang yang berbeda.

Dye yang digunakan dalam DSSC memiliki kromofor terkonjugasi dan dapat mengalami transfer elektron. Contoh dye organik yang memiliki antosianin tinggi dan dapat mentransfer elektron adalah Hokianti mikro (carmona retusa). Daun Hokianti mikro mengandung berbagai konstituen yang aktif seperti: asam rosmarinik, flavonoid dan triterpenoid [6].

\subsection{Efisiensi DSSC}

Efisiensi DSSC diukur dengan metode kurva arus-tegangan. Tujuannya adalah untuk mengetahui efektivitas susunan komponen DSSC dalam mengubah energi matahari menjadi listrik, dinyatakan dalam persentase. Kinerja sel surya dapat ditentukan berdasarkan efisiensi konversi energi cahaya ke energi listrik. Nilai efisiensi $\eta$ dari sebuah sel surya dinyatakan dengan persamaan (1) [11].

$$
\eta=\frac{P_{\max }}{P_{\text {Light }}} \times 100 \%
$$

Dimana $P_{\max }$ adalah daya maksimum yang dihasilkan sel surya (dalam W) yang dihitung dengan persamaan (2).

$$
P_{\max }=V_{o c} \times I_{s c} \times F F
$$

Dengan $P_{\text {Light }}=P_{\text {input }}$ merupakan daya dari sinar yang mengenai sel surya (dalam W), sedangkan FF (Fill Factor) adalah ukuran kuantitatif kualitas sel surya yang dinyatakan dengan persamaan (3).

$$
F F=\frac{V_{\max } \times I_{\max }}{V_{o c} \times I_{s c}}
$$

Dimana $I_{\max }$ adalah arus yang dihasilkan pada saat daya maksimum dari solar sel, $V_{\max }$ adalah tegangan yang dihasilkan pada saat daya maksimum dari sel surya, $I_{s c}$ adalah arus yang dihasilkan ketika terjadi hubungan pendek dan $V_{o c}$ adalah tegangan yang dihasilkan ketika rangkaian masih terbuka [12].

\section{Metode Penelitian}

Proses fabrikasi DSSC dilakukan melalui tahapan: preparasi ekstrak dye, preparasi pasta $\mathrm{TiO}_{2}$ dan deposisi lapisan tipis $\mathrm{TiO}_{2}$, preparasi elektrolit, preparasi pasta karbon dan deposisi lapisan tipis karbon. 3.1 Preparasi ekstrak dye

Daun Hokianti mikro dikeringkan tanpa penyinaran langsung agar kandungan antosianin dalam daun tidak hilang, kemudian daun tersebut dihaluskan dengan cara diblender sehingga didapatkan dalam bentuk bubuk. Bubuk tersebut kemudian ditimbang sebanyak 13,5 gram dan ditambahkan aquades dengan tiga variasi konsentrasi yaitu 60,75 dan $90 \mathrm{mg} / \mathrm{mL}$. Larutan dye diaduk dengan magnetic stirer pada suhu pemanasan $80{ }^{\circ} \mathrm{C}$ selama 30 menit agar larutan homogen, kemudian direndam selama \pm 24 jam. Larutan kemudian disaring dengan menggunakan kertas saring Whatman no. 42 yang memiliki mesh $125 \mathrm{~mm}$. Hasil ekstraksi disimpan dalam botol gelap dan diletakkan dalam lemari es.

Selanjutnya sampel dikarakterisasi dengan menggunakan spektrofotometer FTIR untuk mengidentifikasi gugus fungsi yang berperan dalam antosianin yaitu cincin aromatik. Untuk mengetahui struktur morfologi sampel bubuk dan memperkirakan ukuran butiran sampel dilakukan karakterisasi SEM. Hasil ekstraksi dye dikarakterisasi dengan menggunakan spektrofotometer UV-Vis yang bertujuan untuk mengetahui terjadinya absorbsi yang merupakan karakteristik dari antosianin pada rentang panjang gelombang 200-400 $\mathrm{nm}$ [15].

\subsection{Pembuatan pasta $\mathrm{TiO}_{2}$ dan deposisi lapisan tipis $\mathrm{TiO}_{2}$}

Serbuk $\mathrm{TiO}_{2}$ sebanyak 3,5 gram diteteskan ke dalam $15 \mathrm{~mL}$ ethanol sambil diaduk selama kurang lebih 30 menit untuk membentuk pasta $\mathrm{TiO}_{2}$. Selanjutnya pasta $\mathrm{TiO}_{2}$ yang sudah terbentuk dimasukkan ke 
dalam botol dan ditutup rapat [10]. Bagian konduktif kaca ITO diberi batas berbentuk persegi berukuran $1 \times 1 \mathrm{~cm}^{2}$ dan selotif setebal $50 \mu \mathrm{m}$. Kemudian, pasta $\mathrm{TiO}_{2}$ diteteskan di atas kaca ITO selanjutnya diratakan dengan spatula. Setelah kering, selotip dikeluarkan dari kaca ITO. Selanjutnya, kaca ITO yang telah dilapisi larutan $\mathrm{TIO}_{2}$ dipanaskan dengan proses dehidrolisis pada suhu $450^{\circ} \mathrm{C}$ selama 10 menit.

\subsection{Preparasi elektrolit}

Serbuk potassium iodide (KI) 0,8 gram dimasukkan ke dalam $10 \mathrm{~mL}$ polyethylene glycol 4000, kemudian diaduk dan ditambahkan 0,127 gram iodine $\left(\mathrm{I}_{2}\right)$ ke dalam larutan. Larutan elektrolit tersebut disimpan dalam botol tertutup [10].

\subsection{Pembuatan pasta karbon dan deposisi lapisan tipis karbon}

Isopropanol sebanyak $15 \mathrm{~mL}$ diteteskan pada serbuk karbon 3,5 gram sambil diaduk selama \pm 30 menit. Bagian konduktif kaca ITO diberi batas berbentuk persegi berukuran $1 \times 1 \mathrm{~cm}^{2}$ dan selotif setebal $50 \mu \mathrm{m}$. Kemudian, pasta karbon diteteskan di atas kaca ITO selanjutnya diratakan dengan spatula. Setelah kering, selotip dikeluarkan dari kaca ITO. Selanjutnya, kaca ITO yang telah dilapisi karbon dipanaskan dengan proses dehidrolisis pada suhu $450^{\circ} \mathrm{C}$ selama 10 menit.

\subsection{Fabrikasi DSSC}

Struktur sel surya yang digunakan adalah sistem sandwich dengan urutan sebagai berikut: elektroda kerja terdiri dari kaca ITO, lapisan semikonduktor $\mathrm{TiO}_{2}$ dan lapisan aktif dye spacer, larutan elektrolit serta counter elektroda terdiri dari kaca ITO yang dilapisi karbon. Penggunaan spacer dimaksudkan untuk menghindari short pada DSSC. Selanjutnya, kontak sel dibuat dengan menggunakan penjepit buaya pada tepi counter elektroda dan elektroda kerja, kemudian dilakukan karakterisasi arus-tegangan pada DSSC. Selanjutnya diukur nilai $V_{\max }$ dan $I_{\max }$ dengan $P_{\text {input }}=5 \mathrm{~W}$ dan dapat ditentukan nilai efisiensi DSSC dengan menggunakan persamaan (1).

\section{Hasil Dan Pembahasan}

4.1 Karakterisasi bubuk daun Hokianti mikro dengan spektrofotometer fourier transform infrared (FTIR) Hasil karakterisasi spektrofotometer FTIR sampel dengan perbandingan bubuk daun Hokianti mikro terhadap $\mathrm{KBr}$ 3:2, spektrum yang diperoleh ditunjukkan pada Gambar 2. Berdasarkan data yang didapatkan dari hasil analisis grafik spektrofotometer FTIR dari Gambar 2, maka dapat diketahui gugus fungsi dari masing-masing bilangan gelombang yang ditunjukkan pada Tabel 1.

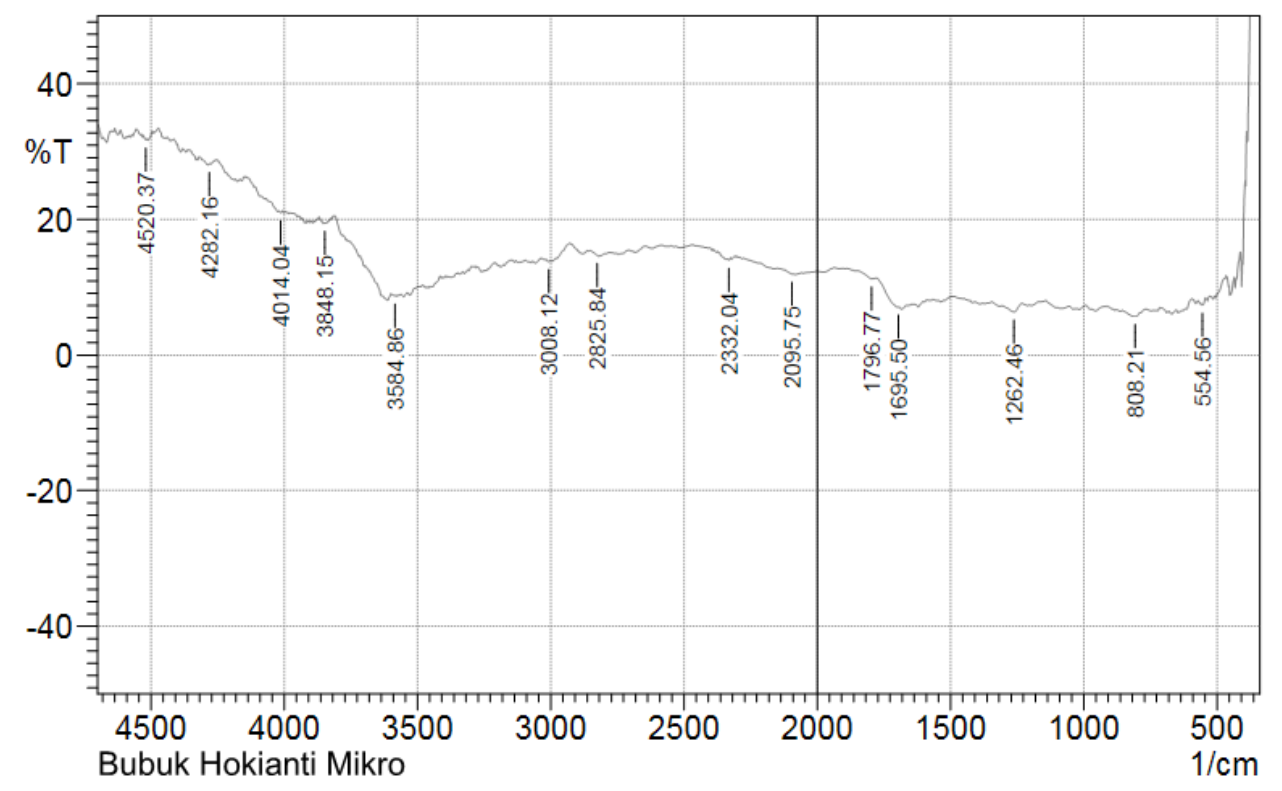

Gambar 2. Spektrumantara transmitansi terhadap bilangan gelombang $(1 / \mathrm{cm})$ bubuk daun Hokianti mikro. 
Tabel 1. Gugus fungsi bubuk daun Hokianti mikro.

\begin{tabular}{lllll}
\hline No & Gugus fungsi & Bilangan Gelombang $\left(\mathrm{cm}^{-1}\right)$ & Intensitas & Tipe Senyawa \\
\hline 1 & C-H & 808,21 & 5,68 & Cincin aromatik \\
2 & N-H & 1262,46 & 6,33 & Amina \\
3 & C=O & 1695,5 & 7,06 & As am karbosilat \\
4 & O-H & 2095,75 & 11,90 & Fenol \\
5 & O-H & 2332,04 & 13,94 & Fenol \\
6 & O-H & 2825,84 & 14,69 & Fenol \\
7 & O-H & 3008,12 & 13,75 & Fenol \\
8 & O-H & 3584,86 & 8,68 & Fenol \\
\hline
\end{tabular}

${ }^{\mathrm{a}}$ dari ref [13].

Dari Tabel 1 diketahui bahwa gugus fungsi bubuk daun Hokianti mikro termasuk gugus fungsi cincin aromatik. Hal ini sesuai dengan hasil penelitian yang menyatakan bahwa antosianin merupakan senyawa berwarna yang berada pada tanaman [13]. Senyawa ini termasuk dalam golongan flavonoid. Struktur utamanya ditandai dengan adanya dua cincin aromatik benzena $\left(\mathrm{C}_{6} \mathrm{H}_{6}\right)$ yang dihubungkan dengan tiga atom karbon yang membentuk cincin. Oleh karena itu, dapat disimpulkan bahwa senyawa hasil ekstrak dari daun Hokianti mikro mengandung antosianin yang dapat berperan pada DSSC.

4.2 Karakterisasi bubuk daun Hokianti mikro dengan scanning electron microscope (SEM)

Gambar 3a adalah contoh hasil karakterisasi SEM salah satu sampel. Dapat teramati terdapat tumpukan butiran-butiran dengan batas-batas yang jelas sehingga dapat diperkirakan ukurannya. Dengan menggunakan software Image-J dan Origin dengan asumsi permukaan butiran berbentuk lingkaran diperoleh ukuran diameter butiran sekitar $(54,13 \pm 0,62) \mu \mathrm{m}$ yang diperlihatkan pada Gambar $3 \mathrm{~b}$.

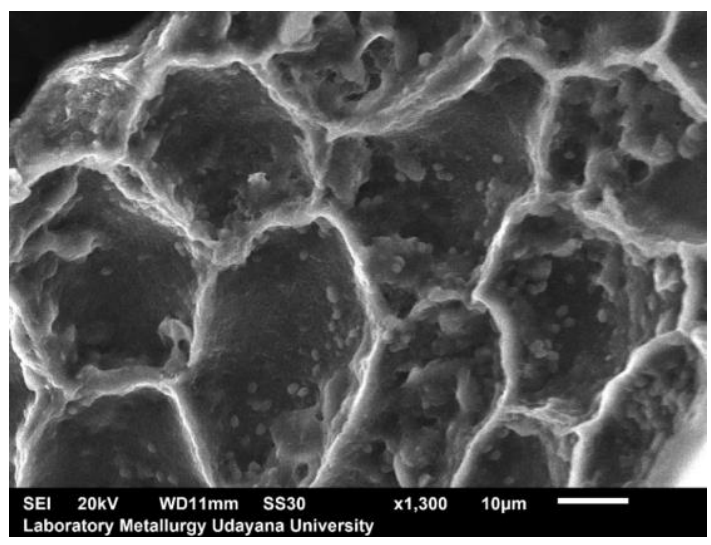

a)

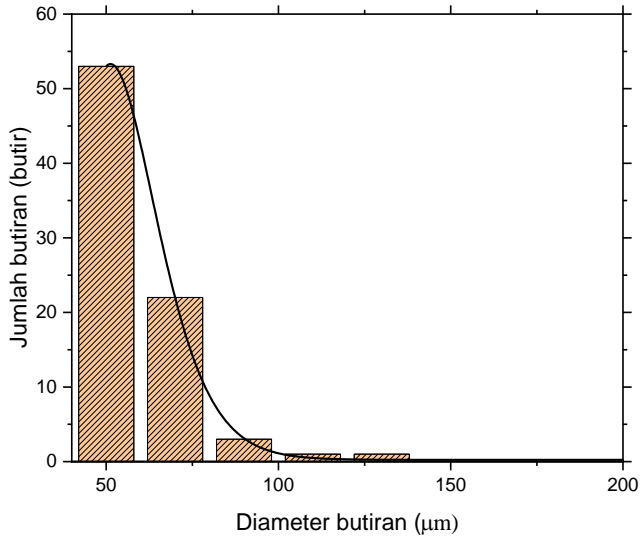

b)

Gambar 3. (a) hasil pengukuran SEM bubuk daun Hokianti mikro dengan pembesaran 1300x dan (b) dis tribusi ukuran diameter butiran sampel daun Hokianti mikro.

Dapat dijelaskan bahwa semakin kecil ukuran butiran, maka dye dapat terabsorpsi pada pori lapisan $\mathrm{TiO}_{2}$ dan mempermudah penyebaran larutan elektrolit. Hal ini menyebabkan nilai efisiensi yang dihasilkan lebih besar daripada yang memiliki ukuran butiran lebih besar, karena foton yang diserap dan pasangan elektron-hole yang dihasilkan lebih banyak [14]. Dengan standar deviasi yang kecil yaitu sebesar 0,26 menunjukkan ukuran butiran bubuk daun Hokianti mikro sudah homogen. Selain itu, nilai $R$-square yang didapatkan sebesar 0,99 yang mendekati angka satu menunjukkan bahwa komponen error yang kecil.

\subsection{Karakterisasi absorbansi dye daun Hokianti mikro menggunakan spektrofotometer UV-Vis}

Hasil spektrum absorbansi pada konsentrasi dye Hokianti mikro 60, 75 dan $90 \mathrm{mg} / \mathrm{mL}$ dengan sumber cahaya UV-Vis ditunjukkan pada Gambar 4. Terlihat pada gambar bahwa dye daun Hokianti mikro menyerap cahaya pada daerah UV dengan dua serapan maksimum pada masing-masing konsentrasi $d y e$ yaitu konsentrasi $60 \mathrm{mg} / \mathrm{mL}$ pada panjang gelombang 223,1 nm dan 277,5 nm, konsentrasi $75 \mathrm{mg} / \mathrm{mL}$ pada panjang gelombang $223 \mathrm{~nm}$ dan $278 \mathrm{~nm}$, serta konsentrasi $90 \mathrm{mg} / \mathrm{mL}$ pada panjang gelombang 223,5 $\mathrm{nm}$ dan $277 \mathrm{~nm}$. 


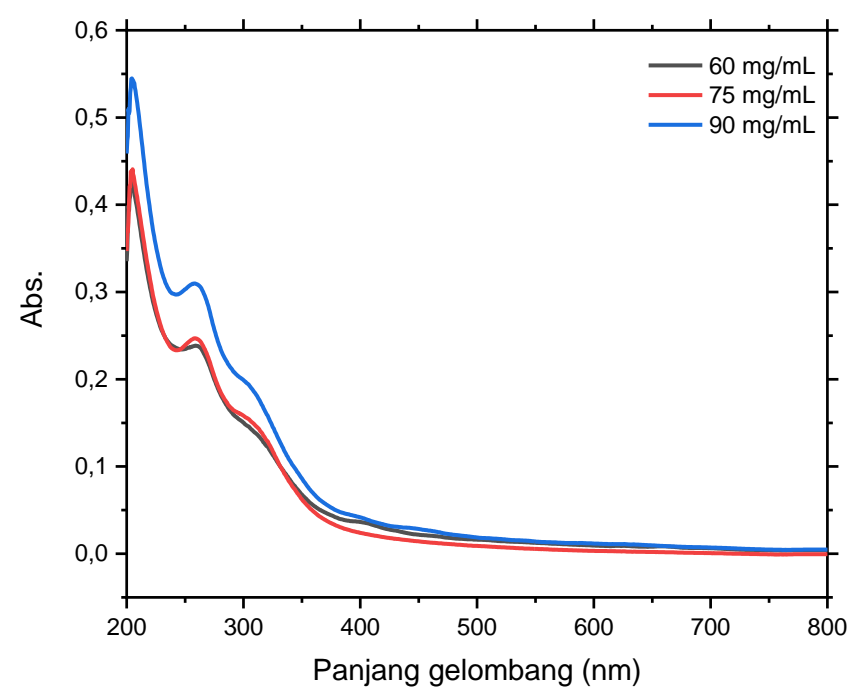

Gambar 4. Spektrum absorbansi dye daun Hokianti mikro dengan spektrofotometer UV-Vis.

Besarnya nilai absorbansi maksimum yang diperoleh untuk masing-masing konsentrasi 60, 75 dan $90 \mathrm{mg} / \mathrm{mL}$ adalah berturut-turut $0,4271,0,4275$ dan 0,5449. Dapat dikatakan bahwa besarnya nilai konsentrasi mempengaruhi nilai berupa absorbansi. Semakin besar konsentrasi yang digunakan, nilai absorbansi juga semakin besar, begitu pula sebaliknya. Besarnya konsentrasi mempengaruhi nilai absorbansi berkaitan dengan peluang terbentuknya eksiton atau pasangan elektron-hole [16]. Banyaknya eksiton yang terbentuk dan mampu mencapai masing-masing elektroda menentukan besar arus yang dihasilkan. Semakin besar nilai konsentrasi yang digunakan, maka transfer muatan menjadi lebih efektif sehingga menyebabkan nilai efisiensi juga semakin besar.

\subsection{Karakterisasi arus-tegangan (I-V) pada DSSC}

Pada DSSC yang telah dirangkai dilakukan pengujian untuk mengetahui kemampuan dalam mengubah energi cahaya menjadi energi listrik. Keberhasilan DSSC dalam mengkonversi energi cahaya menjadi energi listrik ditunjukkan oleh nilai tegangan dan arus listrik yang dihasilkan. Besarnya tegangan, arus dan efisiensi yang dihasilkan dipengaruhi oleh warna lampu dan konsentrasi dye yang digunakan yang ditampilkan pada Tabel 2.

Tabel 2. Tegangan, arus dan efisiensi yang dihasilkan berdasarkan warna lampu dan konsentrasi dye yang digunakan.

\begin{tabular}{|c|c|c|c|c|c|c|}
\hline No & Warna lampu & Konsentrasi $(\mathrm{mg} / \mathrm{mL})$ & $P_{\text {light }}(\mathrm{W})$ & $V_{\max }(\mathrm{V})$ & $I_{\max }(\mathrm{A})$ & $\eta(\%)$ \\
\hline \multirow{3}{*}{1} & \multirow{3}{*}{ Merah } & 60 & 5 & 0,62 & 0,02 & 0,248 \\
\hline & & 75 & 5 & 0,66 & 0,02 & 0,264 \\
\hline & & 90 & 5 & 0,68 & 0,02 & 0,272 \\
\hline \multirow{3}{*}{2} & \multirow{3}{*}{ Orange } & 60 & 5 & 0,76 & 0,04 & 0,608 \\
\hline & & 75 & 5 & 0,80 & 0,04 & 0,640 \\
\hline & & 90 & 5 & 0,84 & 0,06 & 1,008 \\
\hline \multirow{3}{*}{3} & \multirow{3}{*}{ Hijau } & 60 & 5 & 0,84 & 0,04 & 0,672 \\
\hline & & 75 & 5 & 0,86 & 0,08 & 1,376 \\
\hline & & 90 & 5 & 0,96 & 0,08 & 1,536 \\
\hline \multirow{3}{*}{4} & \multirow{3}{*}{ Biru } & 60 & 5 & 0,86 & 0,06 & 1,032 \\
\hline & & 75 & 5 & 0,88 & 0,08 & 1,408 \\
\hline & & 90 & 5 & 1,02 & 0,08 & 1,632 \\
\hline \multirow{3}{*}{5} & \multirow{3}{*}{ Putih } & 60 & 5 & 0,90 & 0,06 & 1,080 \\
\hline & & 75 & 5 & 0,92 & 0,08 & 1,472 \\
\hline & & 90 & 5 & 1,04 & 0,10 & 2,080 \\
\hline
\end{tabular}


Berdasarkan Tabel 2, terlihat bahwa warna lampu putih memiliki efisiensi cahaya paling tinggi jika dibandingkan dengan warna lampu yang lain. Nilai efisiensi tertinggi ini diperoleh pada konsentrasi dye daun Hokianti mikro $90 \mathrm{mg} / \mathrm{mL}$. Hal ini berarti semakin tinggi konsentrasi, semakin banyak dye daun Hokianti mikro mengandung gugus cincin aromatik dan fenol (monomer) pada $\mathrm{TiO}_{2}$ yang mampu menyerap cahaya dan dirubah ke tegangan listrik. Pada Gambar 5, terlihat bahwa DSSC yang disinari dengan warna lampu putih dengan konsentrasi dye daun Hokianti mikro $90 \mathrm{mg} / \mathrm{mL}$ menghasilkan nilai tegangan dan arus paling tinggi yaitu sebesar $1,04 \mathrm{~V}$ dan $0,10 \mathrm{~mA}$. Data konsentrasi $90 \mathrm{mg} / \mathrm{mL}$ ini selanjutnya digunakan untuk menganalisis efisiensi warna lampu dan hasilnya diplot seperti Gambar 5 .

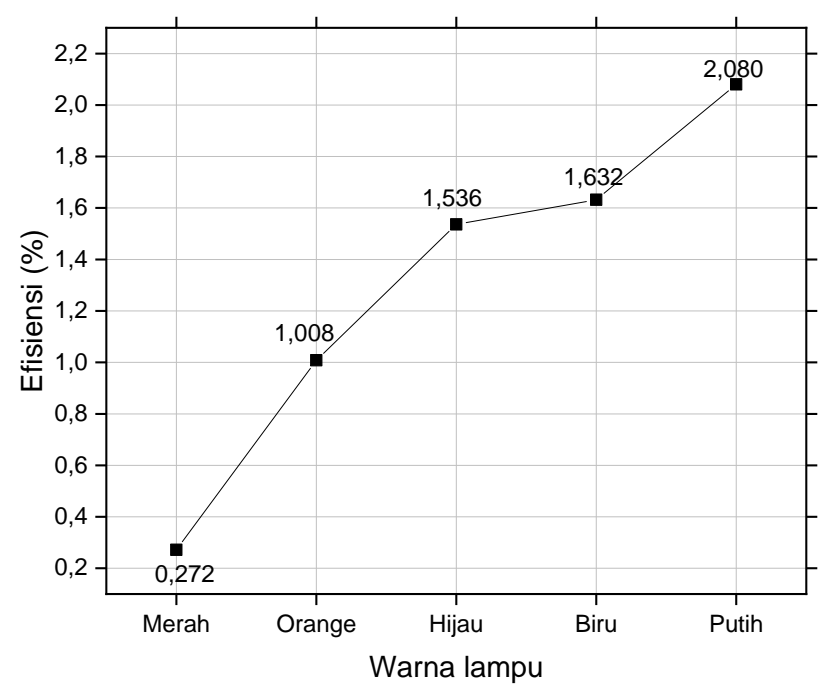

Gambar 5. Grafik hubungan antara warna lampu terhadap efisiensi pada DSSC untuk konsentrasi dye 90 $\mathrm{mg} / \mathrm{mL}$.

Berdasarkan data pada Gambar 5, terlihat bahwa penyinaran warna lampu putih memiliki efisiensi tertinggi, hal ini mengindikasikan bahwa kinerja sel surya dengan warna lampu putih mencakup semua panjang gelombang cahaya yang memiliki performa lebih baik dengan energi paling besar. Energi foton dari warna lampu putih yang diserap oleh dye daun Hokianti mikro mampu melepaskan elektron dari ikatan molekulnya yang mana menyebabkan terjadinya beda potensial diantara elektroda pada DSSC. Dengan adanya serapan pada rentang cahaya tampak yang lebar dapat berpotensi menangkap cahaya matahari lebih banyak, semakin banyak pasangan elektron-hole yang terbentuk dan mencapai elektroda sehingga arus yang mengalir dalam divais semakin besar yang menyebabkan nilai efisiensi meningkat [16]. Hal ini terbukti bahwa konsentrasi dye $90 \mathrm{mg} / \mathrm{mL}$ dan penyinaran dengan warna lampu putih menghasilkan efisiensi paling tinggi yaitu sebesar 2,080\% .

\section{Kesimpulan}

Telah berhasil dibuat DSSC berbasis dye daun Hokianti mikro dengan variasi konsentrasi dye sebesar 60, 75 dan $90 \mathrm{mg} / \mathrm{mL}$. Data menunjukkan bahwa semakin tinggi konsentrasi dye, maka semakin besar nilai efisiensi. Hal ini dipengaruhi oleh serapan cahaya matahari lebih lebar, sehingga arus yang mengalir dalam divais semakin besar dan berpotensi menaikkan nilai efisiensi DSSC. Nilai efisiensi maksimum terjadi pada konsentrasi $90 \mathrm{mg} / \mathrm{mL}$ yang disinari warna lampu putih sebesar 2,080 \%.

\section{Ucapan Terima Kasih}

Terima kasih penulis ucapkan kepada Laboratorium Material Prodi Fisika, Laboratorium Teknik Mesin dan Laboratorium Bersama FMIPA Universitas Udayana atas fasilitas yang diberikan dalam penelitian ini.

\section{Pustaka}

[1] I. Rahardjo and I. Fitriana, Analisis Potensi Pembangkit Listrik Tenaga Surya, Strategi Penyediaan Listrik Nasional Dalam Rangka Mengantisipasi Pemanfaatan PLTU Batubara Skala Kecil, PLTN, dan Energi Terbarukan, pp. 43-52, 2006. 
[2] N. Wendri, P. E. S. Tussniari, and H. Suyanto, Characterization of Salacca Zalacca for Dye Sensitized Solar Cell (DSSC), Buletin Fisika, vol. 20, no. 2, pp. 22-30, 2019, doi: 10.24843/BF.2019.V20.I02.P04.

[3] R. Andari, Sintesis dan Karakterisasi Dye Sensitized Solar Cell (DSSC) dengan Sensitizer Antosianin dari Bunga Rosella (Hibiscus Sabdariffa), Jurnal Ilmu dan Inovasi Fisika, vol. 1, no. 2, pp. 61-71, 2017, doi: 10.24198/jiif.v1i02.12334.

[4] M. Grätzel, Dye-sensitized solar cells, Journal of Photochemistry and Photobiology C: Photochemistry Reviews, vol. 4, no. 2, pp. 145-153, 2003, doi: 10.1016/S1389-5567(03)00026-1.

[5] S. Hao, J. Wu, Y. Huang, and J. Lin, Natural dyes as photosensitizers for dye-sensitized solar cell, Solar Energy, vol. 80, no. 2, pp. 209-214, 2006, doi: 10.1016/J.SOLENER.2005.05.009.

[6] Sam, Ciri Ciri Pohon Hokianti (Ehretia microphylla) Di Alam Liar, https://www.ciriciripohon.com/2019/12/ciri-ciri-pohon-hokianti-di-alam-liar.html, 2019.

[7] M. Priska, N. Peni, L. Carvallo, and Y. D. Ngapa, Antosianin dan Pemanfaatannya, Cakra Kim. (Indonesian E-Journal Appl. Chem., vol. 6, no. 2, pp. 79-97, 2018.

[8] Hardeli, Suwardani, Riky, T. Fernando, Maulidis, and S. Ridwan, Dye Sensitized Solar Cells (DSSC) Berbasis Nanopori $\mathrm{TiO}_{2}$ Menggunakan Antosianin dari Berbagai Sumber Alami, Semirata FMIPA Universitas Lampung, pp. 155-162, 2013.

[9] A. Alimuddin, Perbandingan Efisiensi Dye Sensitized Solar Cell (DSSC) Dari Ekstrak Daun Pacar Air, Bunga Pacar Air Merah Dan Bunga Pacar Air Ungu (Impatiens Balsamina Linn) Sebagai Dye Sensitizer, Skripsi, Jurusan Fisika Fakultas Sains \& Teknologi Universitas Islam Negeri (UIN) Alauddin Makassar, 2016.

[10] D. Nugrahaw ati, Fabrikasi Dye Sensitized Solar Cell (DSSC) Menggunakan Mawar Merah (Rosa Damascena Mill) Sebagai Pewarna Alami Berbasis Antosianin, Skripsi, Jurusan Fisika Fakultas Matematika dan Ilmu Pengetahuan Alam Universitas Sebelas Maret Surakarta, 2012.

[11] C. Honsberg and S. Bowden, Solar Cell Efficiency PVEducation, https://www.pveducation.org/pvcdrom/solar-cell-operation/solar-cell-efficiency, 2018.

[12] R. Pido, S. Himran, and M. Mahmuddin, Analisa Pengaruh Pendinginan Sel Surya Terhadap Daya Keluaran dan Efisiensi, Teknologi, vol. 19, no. 1, Jan. 2019, [Online]. Available from: https://ojs.unm.ac.id/teknologi/article/view/7858.

[13] A. Mahmudatussa'adah, D. Fardiaz, N. Andarwulan, and F. Kusnandar, Karakteristik Warna dan Aktivitas Antioksidan Antosianin Ubi Jalar Ungu, Jurnal Teknologi dan Industri Pangan, vol. 25, no. 2, pp. 176-184, 2014, doi: 10.6066/jtip.2014.25.2.176.

[14] R. D. Astuti, DSSC (Dye Sensitized Solar Cell) Dengan Senyawa Antosianin Dari Kulit Terong Ungu (Solanum Melongena L) Sebagai Photosensitized, Skripsi, Jurusan Fisika Fakultas Matematika dan Ilmu Pengetahuan Alam Universitas Sebelas Maret Surakarta, 2012.

[15] T. J. Bruno and P. D. N. Svoronos, CRC handbook of fundamental spectroscopic correlation charts, Book, 2005.

[16] Chotimah, K. Triyana, I. Kartini, Efek Intensitas Cahaya terhadap Efisiensi Konversi Daya Sel Surya Organik Bulk Heterojunction Berbasis Poly(3-hexylthiophene) dan Phenyl C61 butyric Acid Methylester, Prosiding Pertemuan Ilmiah HFI, pp. 68-72, 2012. 